\title{
Transcriptional profile of the homologous recombination machinery and characterization of the EhRAD5 I recombinase in response to DNA damage in Entamoeba histolytica

\author{
Mavil López-Casamichana ${ }^{1}$, Esther Orozco ${ }^{2}$, Laurence A Marchat ${ }^{3}$ and \\ César López-Camarillo*1
}

Address: ${ }^{1}$ Posgrado en Ciencias Genómicas, Universidad Autónoma de la Ciudad de México, México DF, México, ${ }^{2}$ Departamento de Patología Experimental, CINVESTAV-IPN, México DF, México and '3Programa Institucional de Biomedicina Molecular, ENMH-IPN, México DF, México

Email: Mavil López-Casamichana - gerry2410@yahoo.com; Esther Orozco - esther@cinvestav.mx; Laurence A Marchat - Imarchat@gmail.com; César López-Camarillo* - genomicas@yahoo.com.mx

* Corresponding author

Published: 10 April 2008

BMC Molecular Biology 2008, 9:35 doi:10.1 186/1471-2199-9-35

This article is available from: http://www.biomedcentral.com/I47|-2/99/9/35

(c) 2008 López-Casamichana et al; licensee BioMed Central Ltd.

This is an Open Access article distributed under the terms of the Creative Commons Attribution License (http://creativecommons.org/licenses/by/2.0), which permits unrestricted use, distribution, and reproduction in any medium, provided the original work is properly cited.

\begin{abstract}
Background: In eukaryotic and prokaryotic cells, homologous recombination is an accurate mechanism to generate genetic diversity, and it is also used to repair DNA double strand-breaks. RAD52 epistasis group genes involved in

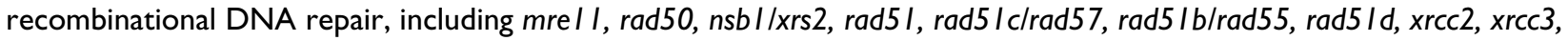
rad52, rad54, rad54b/rdh54 and rad59 genes, have been studied in human and yeast cells. Notably, the RAD5I recombinase catalyses strand transfer between a broken DNA and its undamaged homologous strand, to allow damaged region repair. In protozoan parasites, homologous recombination generating antigenic variation and genomic rearrangements is responsible for virulence variation and drug resistance. However, in Entamoeba histolytica the protozoan parasite responsible for human amoebiasis, DNA repair and homologous recombination mechanisms are still unknown.
\end{abstract}

Results: In this paper, we initiated the study of the mechanism for DNA repair by homologous recombination in the primitive eukaryote $E$. histolytica using UV-C $\left(150 \mathrm{~J} / \mathrm{m}^{2}\right)$ irradiated trophozoites. DNA double strand-breaks were evidenced in irradiated cells by TUNEL and comet assays and evaluation of the EhH2AX histone phosphorylation status. In E. histolytica genome, we identified genes homologous to yeast and human RAD52 epistasis group genes involved in DNA double strand-breaks repair by homologous recombination. Interestingly, the $E$. histolytica RAD52 epistasis group related genes were differentially expressed before and after UV-C treatment. Next, we focused on the characterization of the putative recombinase EhRAD5I, which conserves the typical architecture of RECA/RAD5I proteins. Specific antibodies immunodetected EhRAD5I protein in both nuclear and cytoplasmic compartments. Moreover, after DNA damage, EhRAD5I was located as typical nuclear foci-like structures in E. histolytica trophozoites. Purified recombinant EhRAD5 I exhibited DNA binding and pairing activities and exchanging reactions between homologous strands in vitro.

Conclusion: E. histolytica genome contains most of the RAD52 epistasis group related genes, which were differentially expressed when DNA double strand-breaks were induced by UV-C irradiation. In response to DNA damage, EhRAD5 I protein is overexpressed and relocalized in nuclear foci-like structures. Functional assays confirmed that EhRAD5I is a bonafide recombinase. These data provided the first insights about the potential roles of the $E$. histolytica RAD52 epistasis group genes and EhRAD5I protein function in DNA damage response of this ancient eukaryotic parasite. 


\section{Background}

Entamoeba histolytica, the protozoan causative of human amoebiasis, has a world-wide distribution with a higher prevalence in developing countries, affecting more than 50 million people each year [1]. Trophozoites show a dramatic virulence variability that could be related to great genome plasticity [2]. Frequent ploidy changes, unscheduled gene amplification and duplication have been reported $[3,4]$, and it has been largely assumed that these processes are linked to genetic rearrangements, although no direct experimental evidence has been provided yet.

In eukaryotic and prokaryotic cells, homologous recombination (HR) is an accurate mechanism to generate genetic diversity. HR is also used by cells to properly repair the DNA double strand-breaks (DSBs). Generally, this kind of damage is produced by genotoxic agents or during cellular processes like meiotic division, telomere maintenance, and restoration of collapsed replication forks in the course of DNA synthesis [5-7]. Cellular response to DNA DSBs activates a complex network of proteins that transiently arrests cell cycle and enhances DNA repair mechanisms. Particularly, Saccharomyces cerevisiae H2A and Homo sapiens H2AX histones are rapidly phosphorylated in the chromatin micro-environment surrounding DNA DSBs, inducing nucleosome remodeling to promote accumulation of checkpoint and DNA repair proteins at these sites [8]. In case of extreme DNA damage, cells are targeted to apoptosis [9]. Additionally, HR is also a useful tool to analyze gene function by gene targeting and gene knock out approaches [10].

Molecular genetics of HR DNA repair has been well preserved throughout evolution. RAD52 epistasis group genes involved in DNA DSB repair, including mre11,

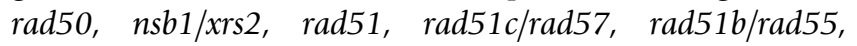
$\operatorname{rad51d}, \operatorname{xrcc} 2, \operatorname{xrcc} 3, \operatorname{rad52}, \mathrm{rad} 54, \mathrm{rad} 54 \mathrm{~b} / \mathrm{rdh} 54$ and $\mathrm{rad} 59$ genes, have been identified in human and yeast cells [11]. Pivotal protein in HR pathway is the RAD51 recombinase, which catalyses strand transfer between a broken DNA and its undamaged homologous strand, allowing damaged region to be repaired [12]. Strand exchange reaction is initiated by RAD51-coating of single-stranded DNA (ssDNA) released from DSBs, to generate a nucleoprotein filament. This active thread binds the intact doublestranded DNA (dsDNA) substrate, searching and locating homologous sequences, and promoting DNA strand exchange in an ATP-dependent manner, forming a heteroduplex structure called D-loop [13]. After DNA damage, RAD 51 protein has been observed in nuclear complexes forming discrete foci, which are considered as the recombinational DNA repair sites [14].

HR remains the predominant mechanism to repair DSBs in lower eukaryotes [15]. RAD51 proteins have been iden- tified in Trypanosoma brucei and Plasmodium falciparum parasites, which perform HR to switch the expression of genes encoding surface membrane glycoproteins and generate antigenic variation [16-18]. Furthermore, recombinational rearrangements are responsible for amplification of the multidrug resistance $p f m d r 1$ gene in $P$. falciparum [19], demonstrating the relevance of HR to generate genomic versatility and plasticity in protozoan parasites.

In this paper, we identified and analyzed the mRNA expression profile of E. histolytica RAD52 epistasis group related genes in response to DNA damage. Additionally, we presented experimental evidence of EhRAD51 function as a recombinase, which suggest its potential role in DNA damage response. These findings constitute the initial efforts to understand the DNA repair mechanism in $E$. histolytica that will contribute to the further elucidation of events regulating genome integrity and variability in this early-branch protozoan.

\section{Results \\ High dose of UV-C light induces DNA fragmentation in trophozoites}

It has been shown in a wide variety of cells that X-rays exposure, UV irradiation and chemicals activate cellular responses to DNA repair [20]. To initiate the study of the mechanisms involved in DNA repair in E. histolytica, we used UV-C light irradiation to induce DNA damage in trophozoites. Our experiments showed that during the first $12 \mathrm{~h}$ after irradiation with $254 \mathrm{~nm}$ UV-C $\left(150 \mathrm{~J} / \mathrm{m}^{2}\right)$, cell survival was not significantly affected (Fig. 1A). Using the same experimental conditions, we analyzed the presence of 3'-hydroxyl DNA ends by TUNEL and FACS assays. In untreated trophozoites, FACS analysis evidenced the presence of $<1 \%$ TUNEL positive cells; meanwhile, $30 \mathrm{~min}$ after treatment, $57.4 \pm 2.74 \%$ of UV-C irradiated cells showed DNA fragmentation (Fig. 1B, upper panels). DNA damage reduction was observed at 3,6 and $12 \mathrm{~h}$ after treatment $(27.11 \pm 4.84,8.79 \pm 3.36$ and $0.77 \pm 2.59 \%$, respectively). Propidium iodide stained cells were checked under the fluorescence microscope to confirm the absence of cytoplasmic stain (Fig. 1B, lower panels).

The comet assay (single-cell gel electrophoresis) is widely used to measure DNA damage and repair. Results obtained through neutral comet assay (Fig. 1C) confirmed the induction of DSBs in trophozoites by UV-C treatment. Typical comet-like structures were observed at $30 \mathrm{~min}$ and $3 \mathrm{~h}$, while a reduction of the DNA tails was observed at 6 $\mathrm{h}$ after UV-C treatment. As expected, $12 \mathrm{~h}$ after the genotoxic insult, DNA migration was similar to the control untreated cells (No UV-C). Taking altogether, these data indicated that UV-C irradiation efficiently induced DNA damage and consequently, repair mechanisms were activated to restore DNA integrity allowing cell survival. 
A

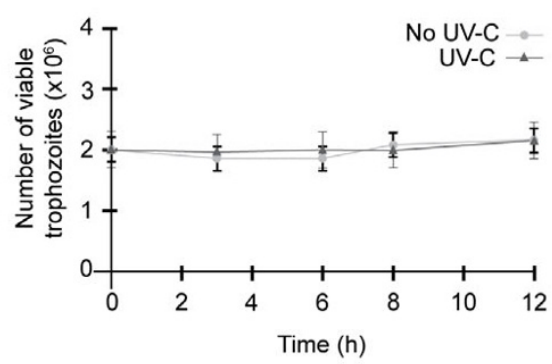

B
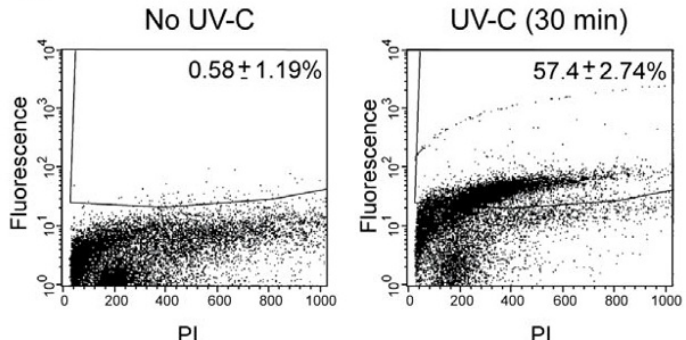

$\mathrm{PI}$

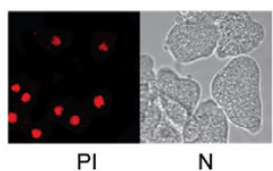

C

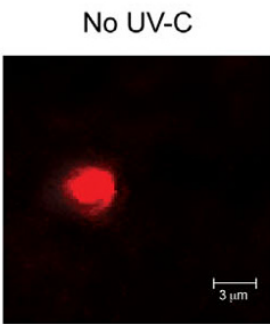

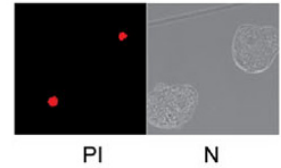

UV-C (30 min)

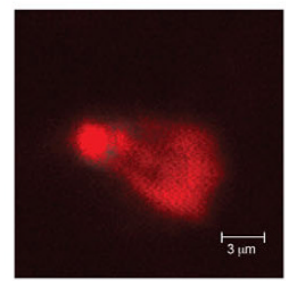

UV-C (3 h)
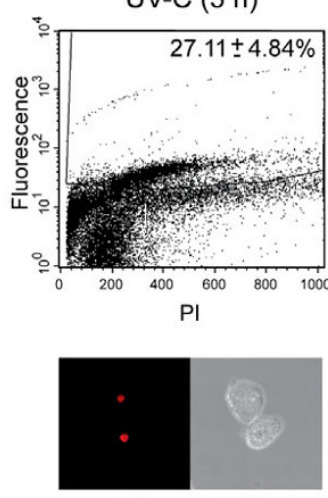

PI

UV-C (3 h)

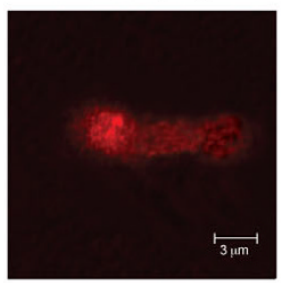

UV-C (6 h)
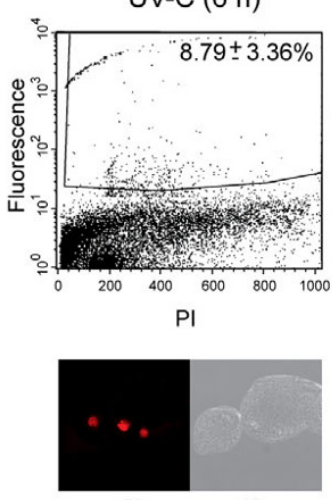

PI

UV-C (6 h)

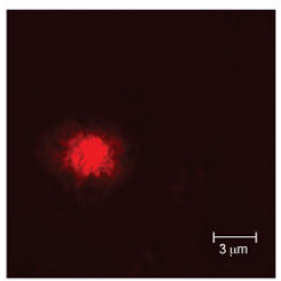

UV-C (12 h)
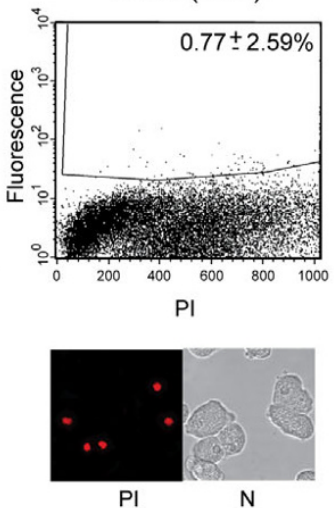

UV-C (12 h)

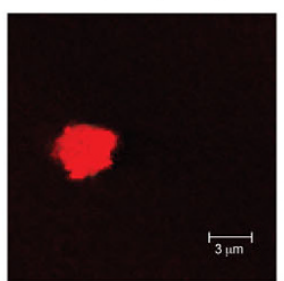

\section{Figure I}

Effect of UV-C irradiation on cell viability and DNA integrity of trophozoites. A. Growth curves of non-irradiated and irradiated trophozoites ( $150 \mathrm{~J} / \mathrm{m}^{2}$ of UV-C light for $8 \mathrm{~s}$ ). B. TUNEL assay and flow cytometry (FACS) assays of non-irradiated (No UV-C) and irradiated (UV-C) trophozoites harvested at different times (30 min, 3, 6 and I2 h). Upper panels, histograms show the DNA fragmentation percentage in fluorescence positive cells. The abscissa indicates fluorescence of propidium iodide (PI), and the ordinate indicates fluorescence of Alexa 488-labeled 3' ends of DNA. The number inside each histogram denotes the percentage of fluorescence positive cells above the cut-off line. Lower panels, PI-staining cells were checked in the epifluorescence microscope to confirming the absence of cytoplasmic stain. PI, propidum iodide, N, Nomanski optics. C. Neutral comet assays of non-irradiated (No UV-C) and irradiated (UV-C) trophozoites harvested at different times (30 min, 3, 6 and $I 2 \mathrm{~h}$ ). Electrophoretic migration of DNA was from left (anode) to right (cathode).

\section{Early EhH2AX histone phosphorylation correlates with the} presence of DNA DSBs

DNA DSBs induce early phosphorylation of yeast $\mathrm{H} 2 \mathrm{~A}$ (major H2A closer to mammalian H2AX) and human $\mathrm{H} 2 \mathrm{AX}$ histones on a conserved serine residue located in the SQ motif at $\mathrm{C}$ terminus, producing $\gamma \mathrm{H} 2 \mathrm{~A}$ and $\gamma \mathrm{H} 2 \mathrm{AX}$, respectively [21]. As in yeast, E. histolytica seems to have replaced the canonical $\mathrm{H} 2 \mathrm{~A}$ with $\mathrm{H} 2 \mathrm{AX}$ [22]. Two genes (locus EHI_126210 and EHI_188960) that encode putative proteins with 55 and $57 \%$ identity ( $e$-value $2 e$-27and 
2e-28) to yeast H2A and human H2AX histones, respectively, were found in the E. histolytica genome. These genes predict two $17.6 \mathrm{kDa}$ conserved paralogous H2AX proteins that share $93 \%$ identity. Notably, both contain the H2AX exclusive SQ motif with the potentially phosphorylable serine residue (S156) (Fig. 2A).

Taking advantage of the high conservation between $H$. sapiens and E. histolytica H2AX C-terminus, we performed Western blot assays using the anti-human $\gamma \mathrm{H} 2 \mathrm{AX}$ antibody to detect serine-phosphorylated EhH2AX homologues $(\gamma$ EhH2AX) in cytoplasmic (CE) and nuclear (NE) extracts of trophozoites. Protein amount and integrity were confirmed on Coomassie blue stained-gels (data not shown). In NE from non-irradiated cells, we identified a $17-\mathrm{kDa}$ weak band, which corresponds to the expected molecular weight of $\gamma \mathrm{EhH} 2 \mathrm{AX}$ histones (Fig. 2B, lane 2). Interestingly, 10 min after UV-C irradiation, this band was five-fold more intense, suggesting an increase in the amount of nuclear $\gamma$ EhH2AX, and 30 min after treatment no band was found (Fig. 2B, lanes 4 and 6). However, these assays did not allow us to distinguish whether one or both EhH2AX proteins were phosphorylated. In contrast, no signals were observed in CE (Fig. 2B, lanes 1, 3 and 5). We used as an integrity control an anti-EhPAP serum, which recognized the 63-kDa EhPAP protein [23] in non-irradiated and irradiated trophozoites (Fig. 2B, middle panel). In addition, an anti-actin monoclonal antibody, used as control for cell fractionation, strongly detected the expected 42-kDa band in CE and a slight signal in NE, as expected for a major component of cytoskeleton (Fig. 2B, lower panel). These data showed that UV-C irradiation of trophozoites is a useful model to generate DNA DSBs and study DNA repair in E. histolytica.

\section{E. histolytica genome contains RAD52 epistasis group related genes}

In order to investigate the presence of RAD52 epistasis group related genes in E. histolytica genome, we surveyed the parasite Pathema database (Table 1). We found Ehmre11, Ehrad50 and Ehnbs1 genes, which could encode the E. histolytica putative MRE11-RAD50-NBS1 protein complex that functions as the primary sensor of DNA DSBs in other organisms [9]. Both EhMRE11 and EhRAD50 proteins exhibited 32 to $23 \%$ identities (e-values from $3 e-49$ to $9 e-36$ ) with $S$. cerevisiae and $H$. sapiens orthologous proteins, respectively; whereas the EhNBS1 sequence appears to be more divergent ( 17 to $24 \%$ identity and $e$-values from 0.003 to 0.002$)$. E. histolytica also contains genes encoding the putative recombinase EhRAD51 and its paralogous protein EhRAD51C. EhRAD52, EhRAD54, EhRAD54B and EhRAD59 (EhRAD52/22 in Pathema database) predicted proteins are also encoded in the E. histolytica genome. As in yeast,
A

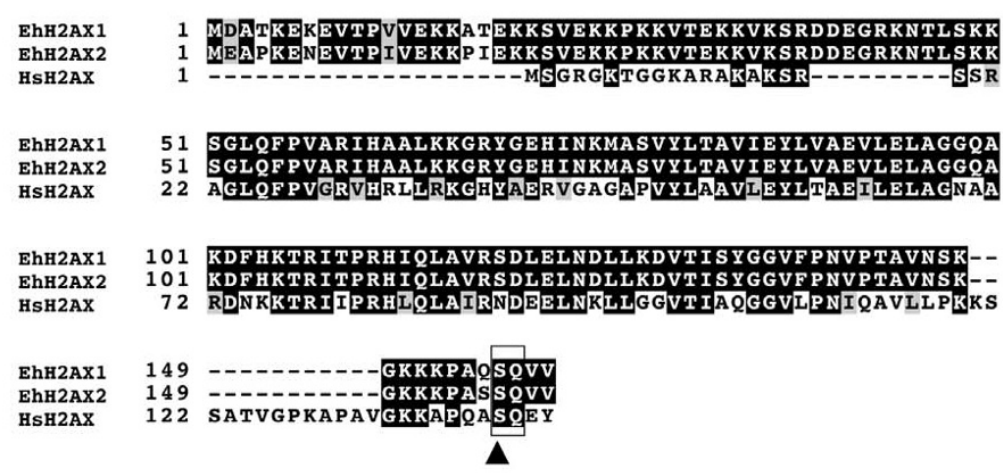

B

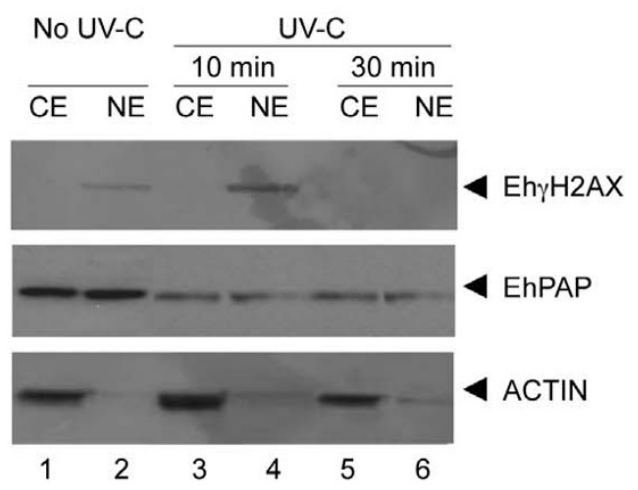

\section{Figure 2}

Identification and immunodetection of phosphorylated EhH2AX histones ( $\gamma$ EhH2AX). A. Multiple sequence alignments of $E$. histolytica and $H$. sapiens $\mathrm{H} 2 \mathrm{AX}$ histones sequences. Black boxes, identical residues; grey boxes, conserved substitutions; open box, C-terminal SQ motif. Arrowhead denotes the potential phosphorylable serine residue (SI56). Numbers at left are relative to the position of the initial methionine in each protein. B. Immunodetection of phosphorylated $\gamma E h H 2 A X$ polypeptides by Western blot assays using anti-human $\gamma \mathrm{H} 2 \mathrm{AX}$ polyclonal antibody (upper panel). CE, cytoplasmic extracts; NE nuclear extracts. Lanes I and 2, non-irradiated (No UV.C) trophozoites; lanes 3 and 4, irradiated trophozoites (I0 min after UV-C treatment); lanes 5 and 6, irradiated (UV-C) trophozoites (30 min after UV-C treatment). Controls using anti-EhPAP and anti-actin antibodies (middle and bottom panels, respectively) are shown. 
Table I: Comparison of E. histolytica, H. sapiens and S. cerevisiae RAD52 epistasis group proteins

\begin{tabular}{|c|c|c|c|c|c|c|c|c|c|c|c|c|c|c|c|}
\hline \multicolumn{4}{|c|}{ Entamoeba histolytica } & \multicolumn{6}{|c|}{ Homo sapiens } & \multicolumn{6}{|c|}{ Saccharomyces cerevisiae } \\
\hline $\begin{array}{l}\text { Predicted } \\
\text { protein }\end{array}$ & Size (aa) & $\begin{array}{l}\text { GeneBank } \\
\text { ID }\end{array}$ & Locus name ${ }^{a}$ & Protein & $\begin{array}{l}\text { Accession } \\
\text { number }^{b}\end{array}$ & Size (aa) & e-value & $\mathrm{H}(\%)$ & I (\%) & Protein & $\begin{array}{l}\text { Accession } \\
\text { number }^{b}\end{array}$ & Size (aa) & e-value & $\mathrm{H}(\%)$ & I (\%) \\
\hline EhMREII & 596 & $\underline{X M \quad 651393}$ & EHI_I25910 & MREII & P49959 & 708 & $3 e-49$ & 51 & 32 & MREII & P32829 & 692 & le-33 & 45 & 26 \\
\hline EhMREII-like & 223 & XM 644963 & EHI_077650 & MREII & P49959 & 708 & $3 e-23$ & 51 & 25 & MREII & P32829 & 692 & $2 e-20$ & 49 & 27 \\
\hline EhRAD50 & $|24|$ & XM 647783 & EHI_079960 & RAD50 & Q92878 & 1312 & $2 e-44$ & 40 & 23 & RAD50 & PI2753 & 1312 & $2 e-43$ & 46 & 27 \\
\hline EhNBSI & 764 & XM 647447 & EHI_098770 & NBSI & Q6IQ31 & 754 & 0.0022 & 40 & 24 & XRS2 & P33301 & 854 & $e+3$ & 28 & 17 \\
\hline EhRAD5I & 367 & XM 648984 & EHI_03 I 220 & RAD5I & Q06609 & 339 & e- 125 & 83 & 71 & RAD5I & P25454 & 400 & $2 e-43$ & 78 & 60 \\
\hline EhRAD5IC & 284 & $\underline{X M ~ 619126}$ & EHI_I 22860 & RAD5IC & Q433502 & 376 & $3 e-17$ & 51 & 28 & RAD57 & P2530I & 460 & e-109 & 47 & 27 \\
\hline- & - & - & & RAD5IB & O15315 & 350 & - & - & - & RAD55 & P38953 & 406 & - & - & - \\
\hline- & - & - & & RAD5ID & O7577I & 289 & - & - & - & - & - & - & - & - & - \\
\hline- & - & - & & $\mathrm{XRCC2}$ & O43543 & 280 & - & - & - & - & - & - & - & - & - \\
\hline- & - & - & & $\mathrm{XRCC} 3$ & O43542 & 346 & - & - & - & - & - & - & & - & - \\
\hline EhRAD52 & 243 & $\underline{X M \quad 648599}$ & EHI_I88230 & RAD52 & P4335I & 418 & $2 e-35$ & 71 & 48 & RAD52 & P06778 & 504 & le-23 & 57 & 38 \\
\hline EhRAD54 & 885 & XM 648260 & EHI_I03840 & RAD54 & Q92698 & 747 & e-II5 & 58 & 41 & RAD54 & P32863 & 898 & e- 106 & 56 & 37 \\
\hline EhRAD54B & 765 & XM 645236 & EHI_II 4930 & RAD54B & Q9Y620 & 910 & e- 130 & 52 & 36 & $\mathrm{RDH} 54$ & P32863 & 920 & e-II4 & 55 & 39 \\
\hline $\begin{array}{l}\text { EhRAD59 } \\
(\text { EhRAD52/22a })\end{array}$ & 190 & $\underline{X M 651011}$ & EHI_II 2840 & - & - & - & - & - & - & RAD59 & Q12223 & 238 & $2 e-08$ & 45 & 25 \\
\hline
\end{tabular}

a $E$. histolytica Pathema datatabase

b Swiss-Prot/TrEMBL databases

$\mathrm{I}$, identity; $\mathrm{H}$, homology

rad51 paralogs (rad51b, rad51d, $x r c c 2$ and $x r c c 3)$ that participate in HR in vertebrates were not found in E. histolytica (Table 1). In conclusion, E. histolytica genome contains a conserved set of repair genes, which suggests that it is skilled to perform recombinational DNA repair.

\section{E. histolytica genes of the RAD52 epistasis group are differentially expressed in response to UV-C irradiation} As a first step towards establishing the role of the E. histolytica RAD52 epistasis group related genes, we evaluated their mRNA expression by semi-quantitative RT-PCR using the UV-C irradiation model described above. Most genes exhibited a differential mRNA expression profile before and after irradiation (Fig. 3). Ehmre11, Ehrad51, Ehrad51c and Ehrad52 genes were transcribed at a very low level in non-irradiated trophozoites; meanwhile mRNA expression was induced from $30 \mathrm{~min}$ to $12 \mathrm{~h}$ after genotoxic damage. Particularly, the Ehrad51 mRNA expression was 16-, 11- and 4-fold increased at $30 \mathrm{~min}, 3 \mathrm{~h}$ and $12 \mathrm{~h}$, respectively, after UV-C irradiation, when compared with untreated cells (Fig. 3A and 3B). On the other hand, the Ehnbs1, Ehrad54 and Ehrad59 genes were abundantly transcribed in untreated trophozoites; however, mRNA levels were down-regulated after UV-C treatment. The Ehrad50 gene expression showed the highest steady-state mRNA levels in non-irradiated trophozoites. At 30 min after UVC irradiation, Ehrad50 transcript levels dropped drastically; $3 \mathrm{~h}$ later, they moderately increased, and at $12 \mathrm{~h}$ they diminished again. In contrast, Ehrad54b gene did not seem to be expressed under the experimental conditions tested here (Fig. 3A and 3B). We observed minimal changes in the 25S rRNA expression used as control (Fig. 3A, lower panel). These data showed that E. histolytica
RAD52 epistasis group related genes were differentially expressed in response to DNA damage.

\section{The predicted EhRAD5 I conserves the typical architecture of RECAIRAD5 I family members}

Since RAD51 recombinases are considered as key enzymes in HR and DNA repair processes in many organisms [24], we focused on the characterization of the E. histolytica EhRAD51 protein. Ehrad51 is an intron-less 1101 bp gene, which encodes a 367 amino acids (aa) polypeptide (40.3$\mathrm{kDa}$ ). Sequence similarity searches by BLAST showed the lowest $e$-values (from $3 e-29$ to $2 e-20$ ) and high identity (from 59 to $75 \%$ ) with many eukaryotic RAD51 proteins, from plants to human, including protozoan parasites. Moreover, EhRAD51 showed 51\% and 36\% identity with Methanococcus voltae RADA and Escherichia coli RECA bacterial recombinases, respectively (Additional file 1). Amino acid sequence alignment of EhRAD51 protein with yeast and human RAD51 orthologs revealed that these proteins share functional and structural conserved motifs (Fig. 4A). EhRAD51 contains the putative polymerization motif (110-113 aa residues), which tethers individual subunits to form quaternary assemblies in human RAD51 protein [24] (Additional file 2). We also identified the ATPase Walker A or phosphate binding loop (P-loop: 152-159 aa residues) and Walker B motifs (240-249 aa residues), the ssDNA binding loops L1 (255-264 aa residues) and L2 (293-311 aa residues), as well as the ATPstacking motif or ATP cap (342-350 aa residues) at the Cterminus, which are essential for nucleofilament assembling and ATP hydrolysis in RAD51/RECA-like recombinases $[26,27]$. Remarkably, the EhRAD51 N-terminus has a low-complexity region of 34-aa highly enriched in glutamic residues, which is not present in homologous 
A

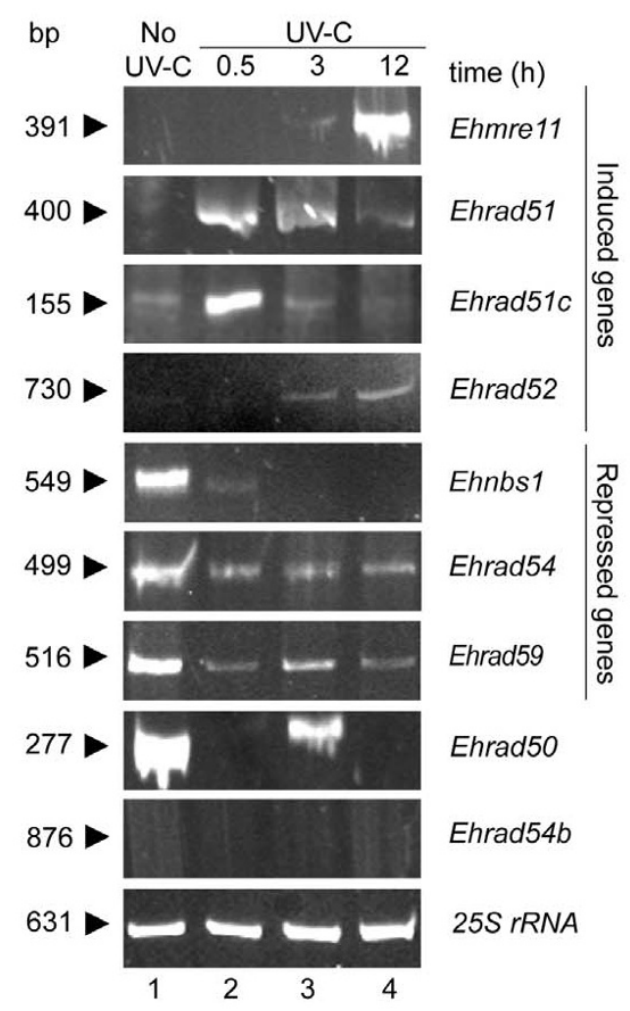

B

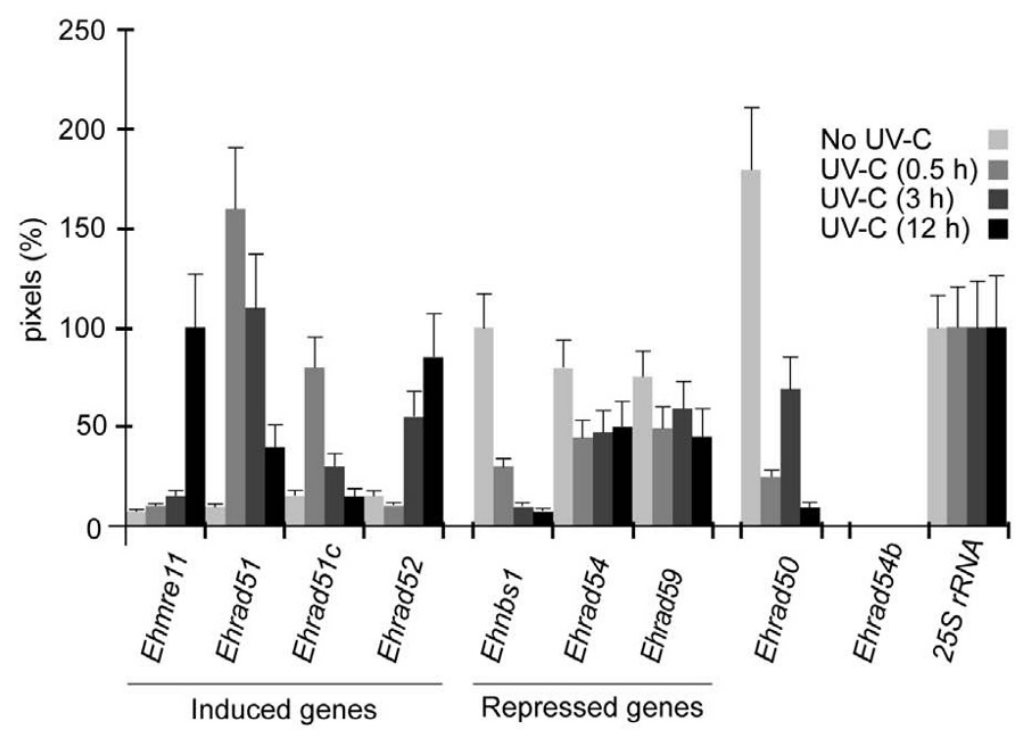

\section{Figure 3}

mRNA expression profiles of E. histolytica RAD52 epistasis group related genes. A. Ethidium bromide stained $6 \%$ PAGE showing the RT-PCR products obtained from I $\mu \mathrm{g}$ of total RNA of non-irradiated (No UV-C, lane I) or irradiated trophozoites harvested at different times (UV-C; lane 2, $0.5 \mathrm{~h}$; lane 3, $3 \mathrm{~h}$ and lane 4, $12 \mathrm{~h}$ ). Arrowheads denote the length (bp) of each expected amplified internal fragment, as described in Table 2. B. Densitometric analyses of RT-PCR products in A. Pixels corresponding to the $25 \mathrm{~S}$ rRNA product were taken as $100 \%$ in each lane. Data are the mean of three independent assays.

proteins (Fig. 4A). Phylogenetic relationships among EhRAD51 and RAD51/RECA related proteins from diverse organisms, revealed a progressive evolution from eubacteria to eukaryotes, being EhRAD51 more related to protozoan recombinases (Fig. 4B).

\section{The EhRAD5 I protein is overexpressed in response to DNA damage}

The recombinant EhRAD51 protein (rEhRAD51) was expressed in E. coli BL21 (DE3) plysS strain as a 6x Histagged fusion polypeptide and subsequently purified by affinity chromatography (Fig. 5A, lanes 3 and 4). By Western blot assays using monoclonal anti-6xHis tag antibodies, the purified rEhRAD51 was detected as a single 47 $\mathrm{kDa}$ band, which was slightly higher than the $44.1 \mathrm{kDa}$ expected weight (Fig. 5B, lane 2). Then, rEhRAD51 was used to generate rabbit polyclonal anti-EhRAD51 antibodies. These antibodies recognized the $47 \mathrm{kDa}$
rEhRAD51 band (Fig. 5B, lane 4), whereas the preimmune serum, used as negative control, did not detect any signal (Fig. 5B, lane 3). To evaluate the expression of the native EhRAD51 in E. histolytica, we performed Western blot assays using anti-EhRAD51 antibodies and protein extracts from irradiated and non-irradiated trophozoites. Antibodies reacted with a weak $46 \mathrm{kDa}$ band in CE from non treated trophozoites, but not signal was detected in NE (Fig. 5C, higher panel, lanes 1 and 2). Meanwhile, at 30 min after UV-C irradiation, antibodies strongly detected the expected $41 \mathrm{kDa}$ endogenous EhRAD51 in CE, but not in NE (Fig. 5C, higher panel lanes 3 and 4). Intriguingly, antibodies also detected a $46 \mathrm{kDa}$ band in both NE and CE from UV-C irradiated trophozoites, which may correspond to a modified form of the $41 \mathrm{kDa}$ protein. The specificity of anti-EhRAD51 antibodies was confirmed performing a similar Western blot assay using anti-EhRAD51 antibodies previously pre-incubated with 


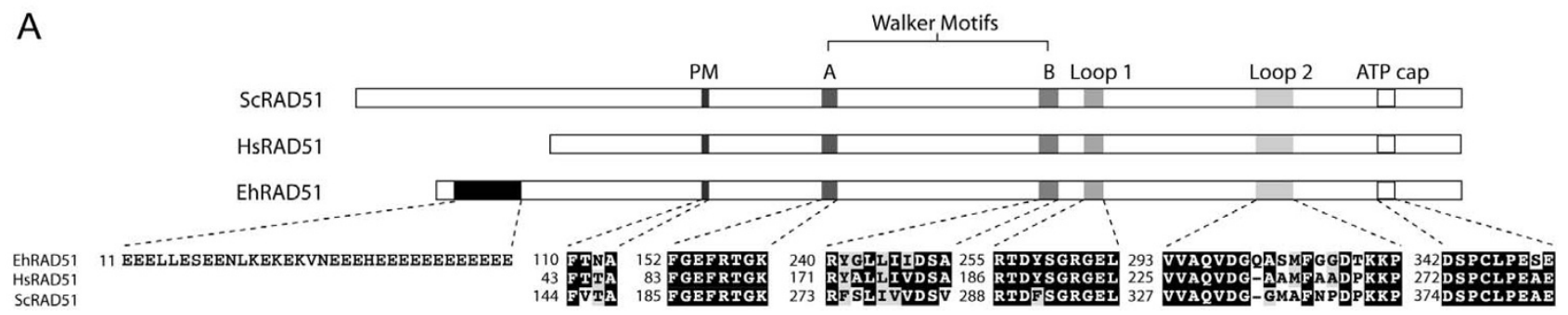

B

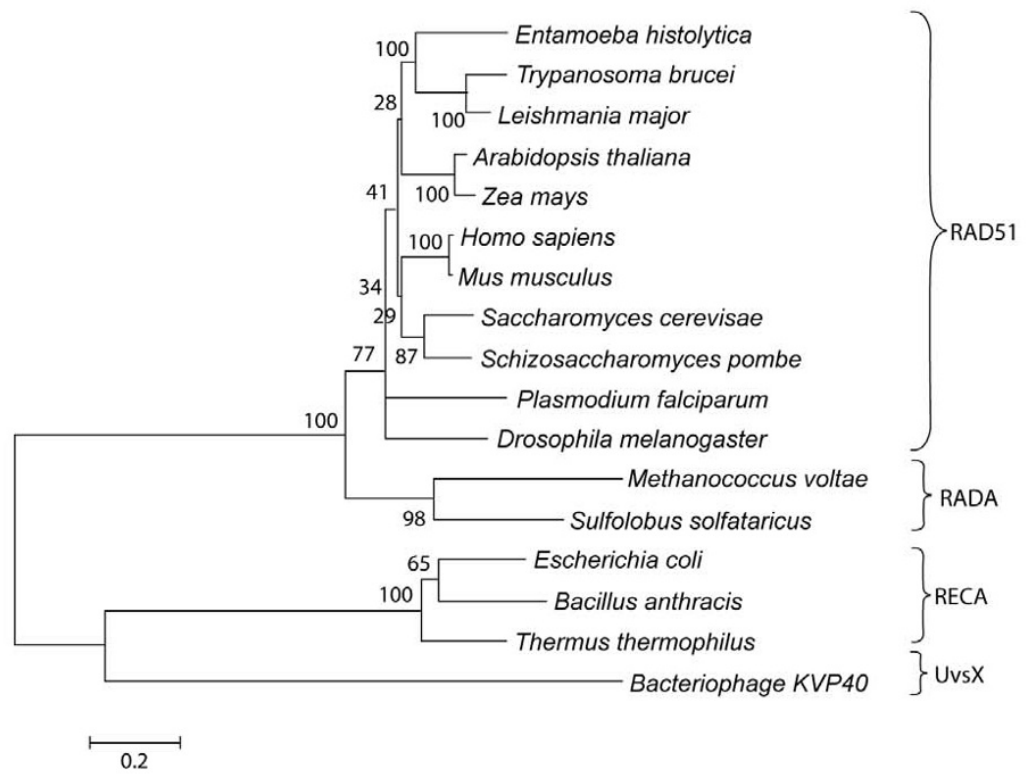

Figure 4

Comparison of the predicted amino acids sequence of EhRAD5 I with other RAD5 I proteins. A. Multiple sequence alignments of functional domains of RAD5I from E. histolytica (EhRAD5I), S. cerevisiae (ScRAD5I) and H. sapiens (HsRAD5I) proteins. Upper panel: Glutamate-rich region, polymerization motif (PM), Walker A and B motif, LI and L2 regions and ATP cap appear as colored boxes. Lower panel: black boxes, identical aa; grey boxes, conserved substitutions; open box, Glutamate-rich region. Numbers at the left are relative to the position of the initial methionine in each protein. Accession numbers and protein lengths are indicated in the Supplementary Table SI. B. Phylogenetic relationships between EhRAD5I and RECA/RAD5I family members. The unrooted tree was created with the MEGA 3.I program using the Neighbor Joining algorithm based on ClustalW alignments of complete amino acids sequences. Numbers above the tree nodes indicate the percentage of times that the branch was recovered in 1000 replications.

purified rEhRAD51 protein and the recognition of both 46 and $41 \mathrm{kDa}$ proteins was specifically inhibited (data not shown). In addition, the use of anti-EhPAP and antiactin antibodies confirmed protein integrity and cell fractionation of CE and NE (Fig. 5C, middle and lower panels). Our findings showed that EhRAD51 was overexpressed in response to UV-C irradiation, and distributed in both nuclear and cytoplasmic compartments.

\section{EhRAD5 I relocalizes into nuclear foci-like structures in response to DNA damage}

In order to better characterize the EhRAD51 expression and function, we investigated its subcellular location in trophozoites through immunofluorescence and laser confocal microscopy. In agreement with the Western blot results, EhRAD51 was detected at low levels in the cytosol of non-irradiated trophozoites (Fig. 6, panels A-D), whereas at $30 \mathrm{~min}$ after UV-C irradiation we noted a dramatic accumulation of cytoplasmic EhRAD51 protein. Interestingly, we also observed a scattered distribution of EhRAD51 typical foci-like structures in the nucleus (Fig. 6, 


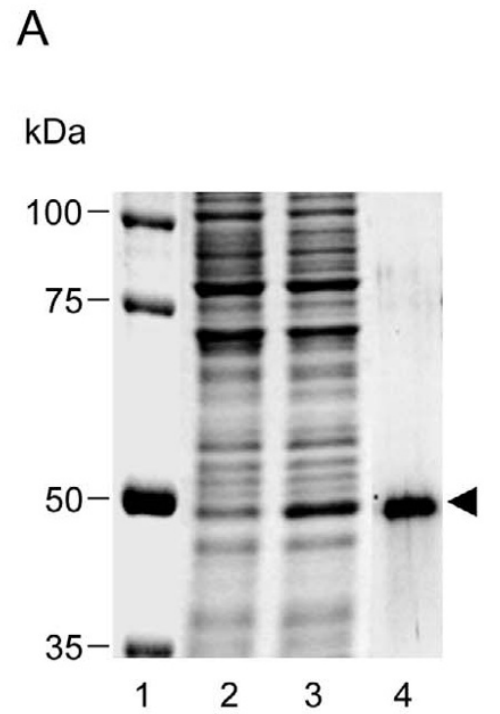

B

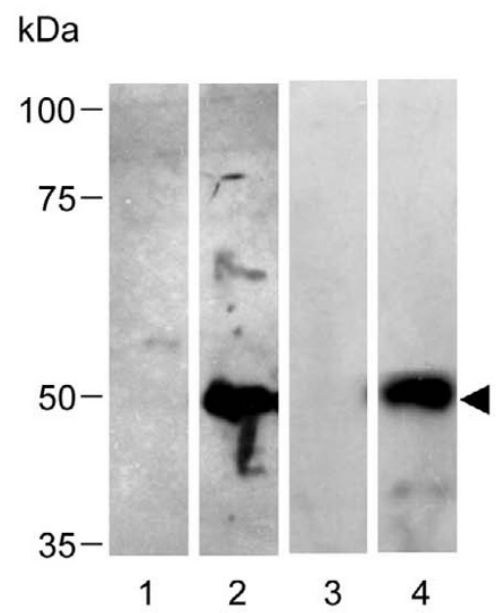

C

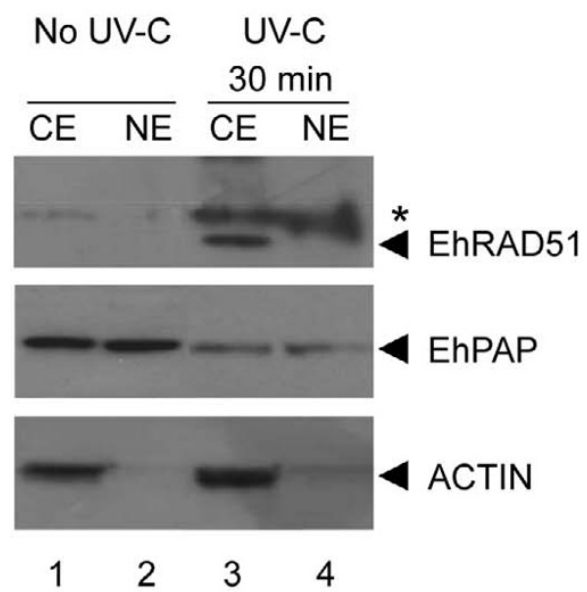

\section{Figure 5}

Expression and immunodetection of EhRAD5 I. A. Expression and purification of rEhRAD5 I-6x His-tagged protein. Bacterial proteins were separated through 10\% SDS-PAGE and gels were stained with Coomassie blue. Lane I, molecular weight markers; lane 2, non-induced bacterial extract ( $30 \mu \mathrm{g})$; lane 3, IPTG-induced bacterial extract (30 $\mu \mathrm{g})$ before passing through the $\mathrm{Ni}^{2+}$-NTA affinity column; lane 4, affinity purified polypeptide from IPTG-induced bacteria extract. Arrowhead, 47 $\mathrm{kDa}$ rEhRAD5I. B. Immunodetection of rEhRAD5I polypeptide. Western blot assays were performed using non-induced bacterial extract (lane I) and purified rEhRAD5 I (lanes 2 to 4). Lanes I and 2; anti-6x His tag antibodies; lane 3, preimmune serum; lane 4, specific rabbit antibodies raised against rEhRAD5I. Arrowhead, 47-kDa rEhRAD5I. C. Immunodetection of $E$. histolytica endogenous EhRAD5 I by Western blot assays using specific anti-EhRAD5 I antibodies. CE, cytoplasmic extracts; NE nuclear extracts. Lanes I and 2, non-irradiated (No UV-C) trophozoites; lanes 3 and 4, irradiated (UV-C) trophozoites (30 min after UV-C treatment). Upper panel: arrowhead, 4I-kDa EhRAD5I; asterisk, 46-kDa EhRAD5I.Controls using anti-EhPAP and anti-actin antibodies (middle and bottom panels, respectively) are shown.

panels E-H). Three hours later, the cytoplasmic signal diminished, while nuclear foci-like structures remained (Fig. 6, panels I-L). At $12 \mathrm{~h}$ after genotoxic damage, both cytoplasmic and nuclear EhRAD51 signals were very weak, being EhRAD51 foci-like structures scarce (Fig. 6, panels M-P). Quantification of nuclear foci like-structures by statistical microscopic analysis showed that about $60 \%$ of the cells contained at least one focus at $30 \mathrm{~min}$ after UV$\mathrm{C}$ irradiation (Fig. 6Q). These findings confirmed that EhRAD51 was up-regulated after UV-C irradiation and suggested that it was redistributed into the nucleus during the first $3 \mathrm{~h}$ after DNA damage.

\section{rEhRAD5 I exhibits DNA binding activity in vitro}

In silico analysis of the EhRAD51 aa sequence evidenced the presence of two putative DNA binding domains. To verify that EhRAD51 is a DNA binding protein, we performed EMSA using increasing amounts of purified rEhRAD51 protein and a fixed concentration of radiolabeled 50-bp ssDNA or 270-bp dsDNA fragments as probes. In order to discard interactions of contaminant $E$. coli proteins with DNA probes, we used mock purified fractions obtained from untransformed bacteria as a negative control. Results showed that incubation of rEhRAD51 with ssDNA and dsDNA probes resulted in five DNA-protein complexes $\left(\mathrm{C}_{\mathrm{I}}-\mathrm{C}_{\mathrm{V}}\right)$ formation, suggesting that alternative populations of RAD51 protomers were associated to each DNA probes (Fig. 7A and 7B, lanes 2 to 4). The fastest migration ssDNA-protein complex $C_{I}$ that was also formed with the mock fraction was considered as unspecific (Fig. 7A, lanes 5 to 7). No complexes were formed in the EMSA control performed with the dsDNA probe (Fig. 7B, lanes 5 to 7 ). Notably, the abundance of slow migration DNA-protein complexes appeared to increase in the presence of the highest rEhRAD51 amount (Fig. 7A and 7B, lanes 2 to 4 ). These results showed that rEhRAD51 was able to efficiently bind both ssDNA and dsDNA substrates in vitro. 

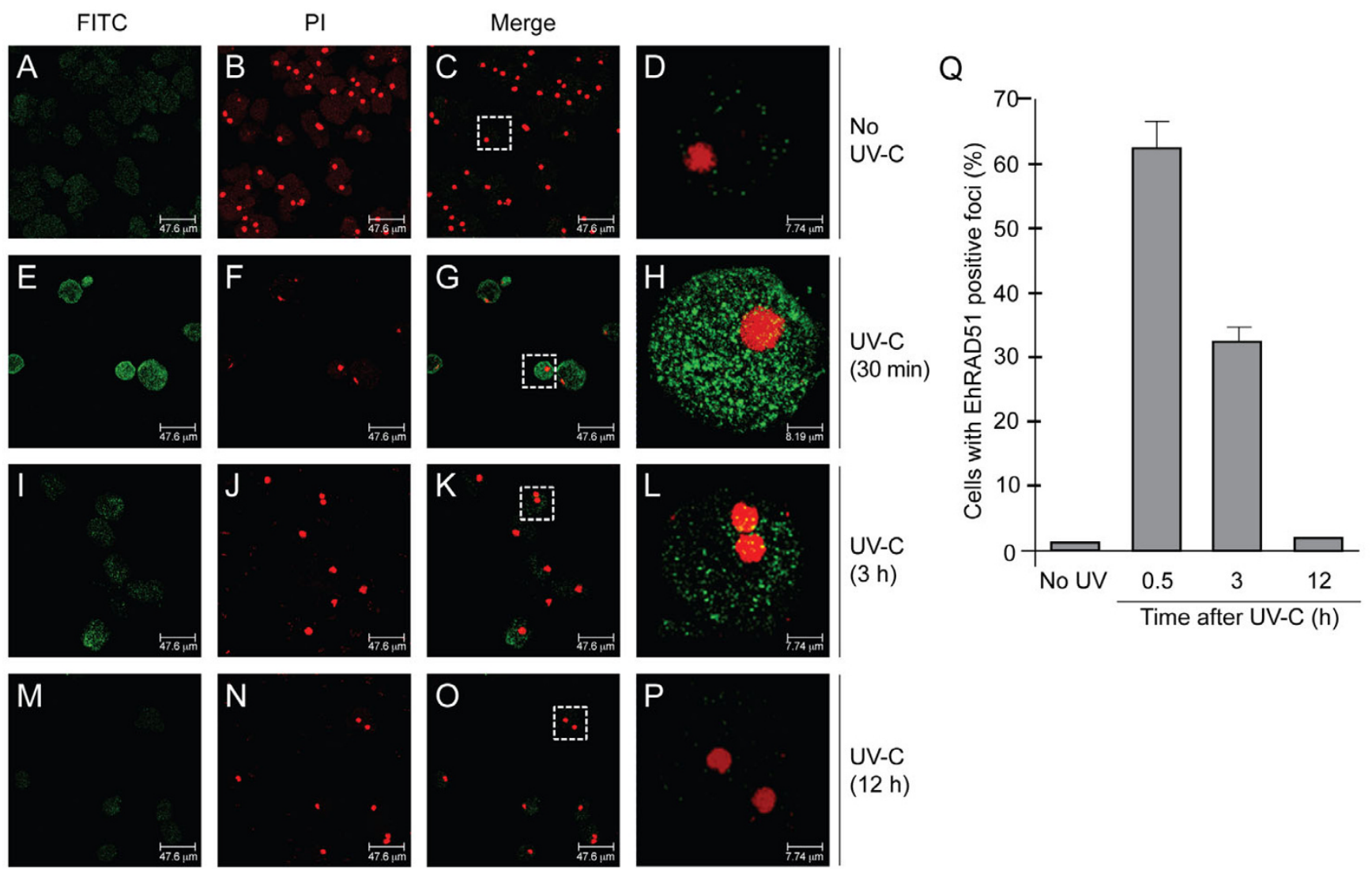

UV-C

$(3 \mathrm{~h})$

$7.74 \mu \mathrm{m}$

\section{Figure 6}

Cellular localization of EhRAD5 I in non-irradiated (No UV-C) and irradiated (UV-C) trophozoites at $30 \mathrm{~min}, 3$ $\mathbf{h}$ and $\mathbf{~} \mathbf{2} \mathbf{h}$ after treatment. Trophozoites were incubated with anti-rEhRAD5I antibodies, treated with FITC-labeled secondary antibodies, counterstained with propidium iodide $(\mathrm{PI})$ and analyzed through confocal immunofluorescence microscopy. A-P. EhRAD5 I immunodetection. A, E, I and M, green channel (FITC); B, F, J and N, red channel (PI) channel; C, G, K and O, merge images; $D, H, L$ and $P$, single cell (I00x magnification) from boxes denoted in $C, G, K$ and O.Q. Occurrence of EhRAD5I nuclear foci. The percentage of trophozoites displaying EhRAD5I foci was calculated after scoring 50 nuclei for each time point. Data are the mean of three independent assays.

\section{rEhRAD5 I exhibits homologous DNA strand transfer activity in vitro}

In order to evaluate the homologous DNA strand transfer function of the rEhRAD51 protein, we performed a pairing assay involving the D-loop structure formation as described in Experimental procedures. Results revealed that rEhRAD51 was able to shift the electrophoretic mobility of the radioactive-labeled 200-bp ssDNA probe incubated with homologous circular dsDNA (Fig. 7C, lanes 2 to 4 ). This indicated that rEhRAD51 was able to catalyze ssDNA transfer to homologous dsDNA forming the three-stranded pairing molecule or D-loop structure, which has a reduced electrophoretic mobility in comparison with the ssDNA probe. The D-loop formation specificity was confirmed by incubation of rEhRAD51 and ssDNA probe in the absence of homologous dsDNA sub- strate (Fig. 7C, lane 5), and in the presence of a heterologous dsDNA substrate (Fig. 7C, lane 6), since no complex was observed. In addition, we did not observe any D-loop structure in the absence of rEhRAD51 (Fig. 7C, lane 1). Densitometric analysis of radioactive products showed that D-loop structure formation using $7.5 \mu \mathrm{g}$ of rEhRAD51 was 3.6 and 1.7-fold higher than with 2.5 and $5 \mu \mathrm{g}$ of rEhRAD51, respectively (Fig. 7D). These results indicated that EhRAD51 protein was able to catalyze specific DNA paring and exchange between DNA homologous strands in vitro.

\section{Discussion}

While non-homologous end joining plays a major role in DSB DNA repair in higher eukaryotes including mammals, HR remains the predominant mechanism to repair 
A

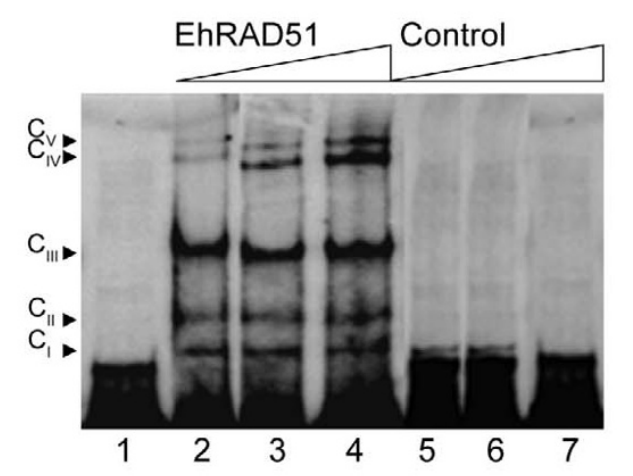

C

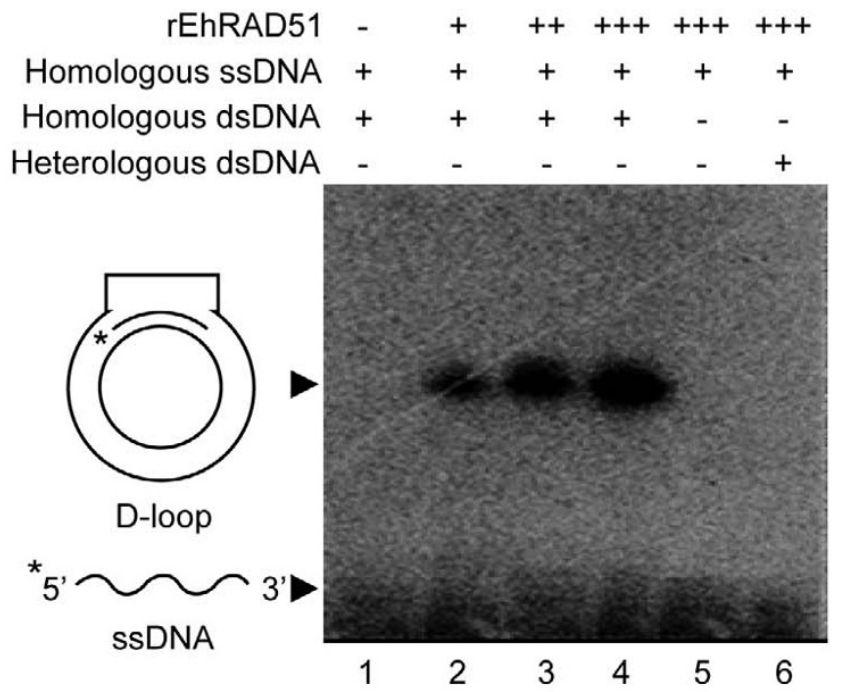

B

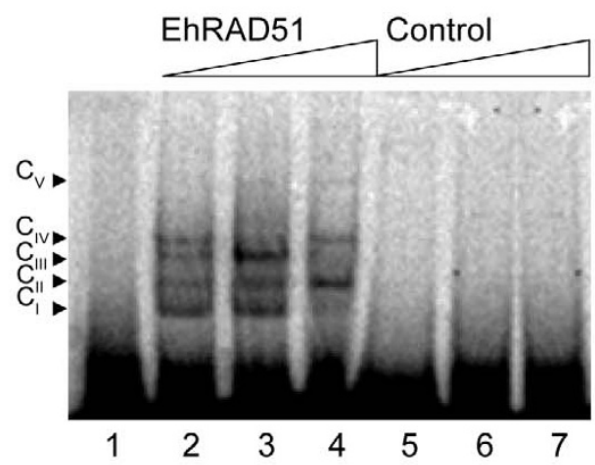

D

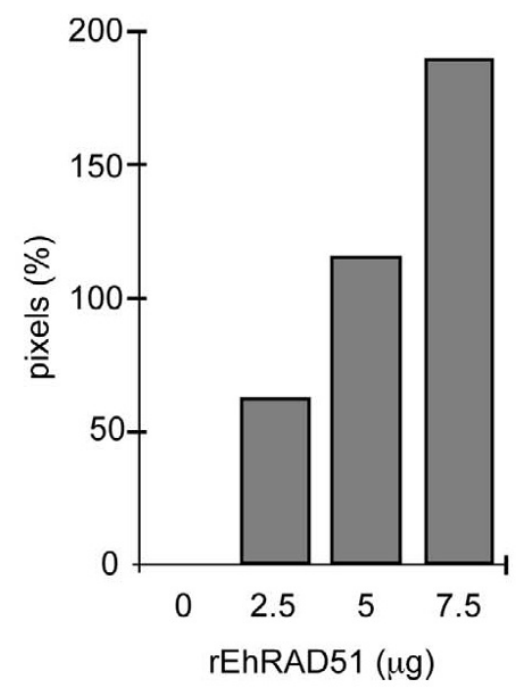

Figure 7

DNA-binding and homologous strand transfer activities of rEhRAD5 I. A. Partially-purified rEhRAD5 I was incubated with $[\gamma-32 P]$ dATP labeled ssDNA and interactions were resolved through non-denaturing PAGE. Lane I, free probe. Lanes 2 to 4, ssDNA incubated with increasing amounts of rEhRAD5I (2.5, 5 and $7.5 \mu \mathrm{g}$, respectively); lanes 5 to 7 , ssDNA incubated with increasing concentrations of mock purified fraction $(2.5,5$ and $7.5 \mu \mathrm{g})$ as control. Protein-DNA complexes $\left(C_{\mid}\right.$to $\left.C_{v}\right)$ are shown by arrowheads. B. Partially purified rEhRAD5 I was incubated with [ $\alpha-32$ P]dATP labeled dsDNA and interactions were resolved through PAGE. Lane I, free probe. Lanes 2 to 4, dsDNA incubated with increasing amounts of rEhRAD5I (2.5, 5 and $7.5 \mu \mathrm{g}$, respectively); lanes 5 to 7, dsDNA incubated with increasing concentrations of mock purified fraction $E$. coli elution fraction $(2.5,5$ and $7.5 \mu \mathrm{g})$ as control. Protein-DNA complexes $\left(C_{1}\right.$ to $\left.C_{v}\right)$ are shown by arrowheads. $C$. D-loop reactions containing $10,000 \mathrm{cpm}$ of $\left[\gamma_{-3} 32 \mathrm{P}\right] \mathrm{dATP}$-labeled oligonucleotide, circular dsDNA and $0,2.5,5$ and $7.5 \mu \mathrm{g}$ of partially-purified rEhRAD5I (lanes I to 4) were incubated at $37^{\circ} \mathrm{C}$ for $30 \mathrm{~min}$ with $2 \mathrm{mM}$ of ATP. Negative controls were performed without homologous dsDNA (lane 5) and with heterologous dsDNA oligonucleotide instead of homologous dsDNA (lane 6), both of them using $7.5 \mu \mathrm{g}$ of EhRAD5 I elution fraction. Reaction products were analyzed by agarose gel electrophoresis, transferred to nylon membranes and visualized through a Phosphor Imager. D. Densitometric analysis of D-loop products obtained in C. Results are representative of two independent experiments. 
this kind of lesions in lower eukaryotes [15]. The high amount of repetitive DNA in protozoan parasites, such as E. histolytica, suggests that the genome of these organisms can be potentially recombinogenic. Therefore, the study of HR process in E. histolytica may advance our understanding about trophozoites genetic and virulence variability, as well as DNA repair mechanisms.

Here, we developed a $254 \mathrm{~nm}$ UV-C light irradiation model, which induces DNA damage in E. histolytica trophozoites and activates recombinational DNA repair pathway. Irradiation dose $\left(150 \mathrm{~J} / \mathrm{m}^{2}\right)$ and time $(8 \mathrm{~s})$ were determined as no lethal conditions for cells in comparison with other UV doses previously evaluated. Growth curves were performed up to $18 \mathrm{~h}$, the doubling time of trophozoites, without observing any significant changes (data not shown). Early phosphorylation of E. histolytica H2AX histones after UV-C irradiation was consistent with DNA DSBs formation, suggesting chromatin remodeling and recruitment of histone-phosphorylating enzymes, as observed in other eukaryotic systems [22]. Moreover, E histolytica trophozoites survival throughout almost $12 \mathrm{~h}$ after irradiation indicated the existence and activation of DNA repair mechanisms. In silico analysis of the E. histolytica genome sequence revealed that this pathogen has genes that encode putative EhRAD52 epistasis group members, which participate in recombinational DNA repair in other organims. Given the place of this ancient protista in the eukaryote phylogenetic scale, EhRAD52 epistasis group had equivalent similarity with homologous proteins from different organisms, such as mammals, plants and other protozoan parasites.

RT-PCR assays evidenced a differential mRNA expression of E. histolytica rad52 epistasis group genes, before and after DNA damage. Some genes (Ehnbs1, Ehrad54 and Ehrad52/22) were down-regulated after DNA damage, others (Ehmre11, Ehrad51, Ehrad51-C and Ehrad52) were up-regulated at different times following genotoxic stimulus, whereas Ehrad50 mRNA levels were regulated in a variable manner, suggesting a complex transcriptional response. Interestingly, Ehrad54b gene did not seem to be transcribed under our experimental conditions. However, in yeast and human, both RAD54 and RAD54B are DNA helicases which participate in the formation of heteroduplex DNA in recombination processes [11]. It is possible that the expression of Ehrad54 homolog is sufficient to cover this activity in trophozoites, although additional experiments are required to confirm this hypothesis. The absence of a coordinated transcriptional activation of Ehrad52 epistasis group genes suggest that trophozoites have enough stationary levels of enzymes for DBB repair and the main regulation could be occurring at translational and/or posttranslational level. A further evaluation of EhRAD52 epistasis group proteins regulation in response to DNA damage will help us to better understand DNA repair by HR in E. histolytica. It seems that the molecular events related to DNA lesions produced by genotoxic agents can be barely inferred from gene expression profiling. Indeed, studies in yeast and mammals have shown no-relationship between genes whose expression is increased after different DNA-damaging treatments (ionizing radiation, UV light, cisplatin, $\mathrm{H}_{2} \mathrm{O}_{2}$ ) and those genes that are involved in protecting against cytotoxicity to the same agents $[28,29]$.

We focused on Ehrad51 gene because RAD51 proteins have been demonstrated as key players in recombinational DNA repair in lower and higher eukaryotes [for review see [12]]. Interestingly, the Ehrad51 transcript steady state levels were about 15 -fold higher at $30 \mathrm{~min}$ post-UV-C treatment and decreased 3 and $12 \mathrm{~h}$ later, suggesting that EhRAD51 could be participating in HR in the early steps of DNA repair. Similar transcriptional activation after UV treatment has been reported as a common characteristic for recA/rad51 homologs of Tetrahymena thermophila [30] and Halobacterium sp. [31]. In agreement with the RT-PCR results, Western blot assays showed a dramatic increase of EhRAD51 in cytoplasm and nucleus, 30 min after DNA breaks were introduced into the E. histolytica genome. The fact that specific polyclonal antibodies immunodetected a $46 \mathrm{kDa}$ EhRAD51 protein suggest that some posttranslational modifications of the cytoplasmic $41 \mathrm{kDa}$ EhRAD51 could be a requirement for its translocation to the nucleus where DNA repair takes place. Taking in consideration that the EhRAD51 sequence lacks a nuclear localization signal, an alternative possibility might be that EhRAD51 needs to interact with other protein(s) to be transported inside the nucleus. However, additional experiments are required to corroborate these hypotheses.

As observed for yeast and human homologs [32], laser confocal microscopy evidenced focal sites of the EhRAD51 protein scattered in the nucleus at $30 \mathrm{~min}$ and $3 \mathrm{~h}$ after DNA damage. Congruently, the EhRAD51 nuclear foci-like structure occurrence was consistent with the DNA fragmentation degree observed in TUNEL and neutral comet assays. Since UV-C treatment did not affect trophozoites viability, it is tempting to suggest that DNA repair mechanisms involving EhRAD51 foci formation were activated to restore genome integrity after genotoxic insult.

In silico analysis demonstrated that the predicted EhRAD51 protein contains all functional and structural motifs that are important for RECA/RAD51 recombinases activities. To experimentally support its role in DNA repair by $H R$, we performed the basic characterization of EhRAD51 protein. EhRAD51 functional properties were 
similar to those previously reported for RAD51 homologous [33-35]. EhRAD51 was able to bind both ssDNA and dsDNA substrates in the presence of ATP and $\mathrm{Mg}^{2+}$. The various rEhRAD51-DNA complexes may be related to different amounts of rEhRAD51 molecules bound to ssDNA or dsDNA probe. Finally, EhRAD51 promoted specific three-stranded pairing structure formation or D-loop. Based on the data presented here, we proposed a working model for DNA DSB repair involving the EhRAD51 recombinase. When a DSB is introduced in E. histolytica genome, EhH2AX histones become phosphorylated, which could induce chromatin remodeling and accumulation of the EhRAD52 epistasis group proteins at the DNA DSB site. We observed that EhRAD51 was relocated into the DNA repair nuclear foci, where it could mediate DNA paring and homologous strand exchange to restore genome integrity. It is also possible that E. histolytica RAD51 protein may play a role in genome rearrangements that naturally occur within this organism during DNA synthesis. Therefore, it will be interesting to evaluate its involvement in frequent ploidy changes, unscheduled gene amplification and duplication events observed in $E$. histolytica genome $[3,4]$. Our next challenge will involve studying in vivo HR and the relevant role of EhRAD51 in this process in E. histolytica.

\section{Conclusion}

Our results provide the first data supporting the role of the RAD52 epistasis group genes in DNA repair process in $E$. histolytica. We showed that E. histolytica RAD52 epistasis group genes, were differentially expressed when DNA fragmentation was induced by UV-C irradiation. We also showed that EhRAD51 protein was overexpressed and relocalized in nuclear foci-like structures after DNA damage, and demonstrated that recombinant EhRAD51 function as a recombinase in vitro. These data evidenced a potential role of EhRAD51 protein in DNA damage response in this ancient eukaryotic parasite.

\section{Methods}

\section{E. histolytica cultures}

Trophozoites of E. histolytica clone A (strain HM1: IMSS) were axenically cultured in TYI-S-33 medium [36] at $37^{\circ} \mathrm{C}$ and harvested during exponential growth phase.

\section{Trophozoites UV-C light irradiation}

Trophozoites $\left(2 \times 10^{6}\right)$ grown in culture bottles were transferred into glass dishes and incubated at $37^{\circ} \mathrm{C}$ for 30 min. Medium and floating cells were discarded, and adhered trophozoites were irradiated with $254 \mathrm{~nm}$ UV-C light at $150 \mathrm{~J} / \mathrm{m}^{2}$ for $8 \mathrm{~s}$ using a UV Stratalinker 1800 device (Stratagene). After treatment, cells were incubated in fresh TYI-S-33 medium at $37^{\circ} \mathrm{C}$ for $0.5,3,6$ and $12 \mathrm{~h}$ to be used in different experiments. Non-irradiated cells were used as a control in all experiments. Cell viability was monitored by microscopy using a trypan blue dye exclusion test. Assays were done three times by duplicate.

\section{Evaluation of DNA fragmentation by TUNEL assay}

Trophozoites $\left(2 \times 10^{6}\right)$ were harvested at $0.5,3,6$ and 12 $\mathrm{h}$ after UV-C irradiation, washed with PBS $1 \times$ and fixed with $1 \%$ paraformaldehyde. After cell permeabilization with 70\% ethanol, DNA damage was quantified using the APO-BrdUTP TUNEL Assay Kit (Molecular Probes) in order to detect 3'-hydroxyl ends in DNA. Permeabilized trophozoites were incubated at $37^{\circ} \mathrm{C}$ for $1 \mathrm{~h}$ in the DNAlabeling solution, which contains terminal deoxynucleotidyl transferase enzyme (TdT) and deoxythymidine analog 5-bromo-2'-deoxyuridine 5'-triphosphate (BrdUTP). Then, cells were washed twice and suspended in antibody staining solution (Alexa Fluor 488 dye-labeled anti-BrdU antibody) at room temperature for $1 \mathrm{~h}$. After that, cells were incubated in propidium iodide/RNase A staining buffer at room temperature for $30 \mathrm{~min}$. Samples were analyzed by flow cytometry in a BD FACS Calibur system and fluorescence data were plotted with the FloJo software.

\section{Evaluation of DNA fragmentation by Comet assay}

Trophozoites $\left(5 \times 10^{4}\right)$ were harvested at $0.5,3,6$ and 12 $\mathrm{h}$ after UV-C irradiation. Neutral comet assay were performed using protocols from Tice and co-workers [37]. Briefly, cells were mixed with agarose and spread over a warmed, precoated microscope slides. Agarose was allowed to solidify at $4{ }^{\circ} \mathrm{C}$, followed by immersion in cold lysis fresh solution $(2.5 \mathrm{M} \mathrm{NaCl}, 100 \mathrm{mM}$ EDTA, $10 \mathrm{mM}$ Tris, pH 7) overnight. Next, electrophoresis was carried out in neutral buffer for $20 \mathrm{~min}$ at $1.5 \mathrm{~V} / \mathrm{cm}$ (measured electrode to electrode) in the dark at $4{ }^{\circ} \mathrm{C}$. Finally, the slides were completely dried and ethidium bromidestained DNA was observed at 400× magnification using an epifluorescence microscope (Leica DMIL).

\section{Detection of phosphorylated EhH2AX histones}

The two Ehh2ax genes, which are homologous to the human h2ax gen, had been previously reported [22]. Their existence in the E. histolytica Pathema database [38] were confirmed by BLAST using yeast $\mathrm{H} 2 \mathrm{~A}$ and human $\mathrm{H} 2 \mathrm{AX}$ protein sequences as queries. The presence of phosphorylated forms of EhH2AX histone ( $\gamma$ EhH2AX) in E. histolytica protein extracts obtained 10 or $30 \mathrm{~min}$ after UV-C irradiation was evaluated by Western blot assays using the anti-phospho-Histone H2AX (pSer ${ }^{139}$ ), which was developed in rabbit using a synthetic phosphorylated peptide corresponding to $134-142$ aa residues (including the phosphorylated Ser) of human H2AX histone C-terminus (Sigma). Subcellular fractionation to obtain CE and NE from clone A trophozoites was performed as described [39]. Proteins were separated by $10 \%$ SDS-PAGE, transferred to nitrocellulose membranes (BioRad) and blocked with $1 \%$ BSA/PBS solution. Then, filters were incubated at 
room temperature for $2 \mathrm{~h}$ with the anti-human $\gamma \mathrm{H} 2 \mathrm{AX}$ polyclonal antibody (1:7000 dilution), washed with PBS $1 \times 0.05 \%$ Tween and incubated at $37^{\circ} \mathrm{C}$ for $1 \mathrm{~h}$ with goat anti-rabbit IgG horseradish peroxidase secondary antibody (Zymed) at 1:10000 dilution. Bands were revealed by ECL Plus Western blotting system (Amersham). As internal controls, we used polyclonal antibodies (1:1000 dilution) raised against the E. histolytica poly(A) polymerase EhPAP and anti-actin antibodies.

\section{In silico identification of E. histolytica genes homologous to yeast RAD52 epistasis group}

RAD52 epistasis group related genes were identified in $E$. histolytica Pathema database using both yeast and human protein sequences as queries. Putative E. histolytica orthologous proteins were selected from BLAST analysis according to the following criteria: (i) at least $20 \%$ identity and $35 \%$ homology to the query sequence; (ii) $e$-value lower than 0.002; and (iii) absence of stop codons in the coding sequence. Predicted aa sequences were aligned by the ClustalW software [40]. Functional domains were predicted by the Prosite program [41]. Phylogenetic inference was performed using the Neighbor-joining distance method [42] as implemented in the Molecular Evolutionary Genetics Analysis (MEGA version 3.1) software [43]. Tree robustness was established by bootstrapping test, involving 1000 replications of the data based on the criteria of $50 \%$ majority-rule consensus.

\section{RT-PCR assays}

Total RNA was obtained using Trizol reagent (Invitrogen) from trophozoites of clone A grown in basal culture conditions or after UV-C treatment. Semi-quantitative RTPCR was performed as previously described [44] using 1 $\mu \mathrm{g}$ of total RNA and specific primers for each gene (Table 2 ). As a control, we amplified a $25 S$ rRNA gene internal sequence. Products were separated by 6\% PAGE, stained with ethidium bromide and submitted to densitometric analysis in a Gel doc 1000 apparatus (BioRad) using the
Quantity One software. Data are the mean of three independent assays.

\section{Cloning of the Ehrad5 I gene}

The 1098-bp full-length Ehrad51 gene was PCR-amplified from genomic DNA of clone A trophozoites using Ehrad51-S (5'-CGGGATCCAAAGTAATGAG TGCCAA GCA-3') sense and Ehrad51-AS (5'-CCAAGCTTGCCATTCTCC GTATTATGGC-3') antisense primers, which contain BamHI and HindIII restriction sites, respectively (underlined). Amplification was performed as follows: $94^{\circ} \mathrm{C}$ for $5 \mathrm{~min}$ and 30 cycles at $94^{\circ} \mathrm{Cfor} 35 \mathrm{~s}, 48^{\circ} \mathrm{C}$ for $35 \mathrm{~s}$ and $72^{\circ} \mathrm{C}$ for $1 \mathrm{~min}$, plus a final extension step at $72^{\circ} \mathrm{C}$ for $7 \mathrm{~min}$, using High Fidelity DNA Taq polymerase (Invitrogen). The PCR product was purified and cloned in frame into the pRSET A expression vector (Invitrogen). The recombinant pRSET -Ehrad51 plasmid construct was confirmed by automated DNA sequencing in an ABI-PRISM 310 (Applied Biosystem) sequencer.

\section{Expression and purification of recombinant EhRAD5 I (rEhRAD5I) protein}

E. coli BL21 (DE3) pLysS bacteria were transformed with pRSET -Ehrad51 plasmid and grown at $37^{\circ} \mathrm{C}$ in 2-TY medium containing $100 \mu \mathrm{g} / \mathrm{ml}$ ampicillin and $34 \mu \mathrm{g} / \mathrm{ml}$ chloramphenicol to an $\mathrm{OD}_{600 \mathrm{~nm}}$ of 0.6 . The expression of rEhRAD51 was induced with $1 \mathrm{mM}$ isopropyl beta-D-thiogalacto pyranoside (IPTG) at $37^{\circ} \mathrm{C}$ for $3 \mathrm{~h}$. Cells were harvested, resuspended in lysis buffer $\left(50 \mathrm{mM} \mathrm{NaH}{ }_{2} \mathrm{PO}_{4}\right.$, $300 \mathrm{mM} \mathrm{NaCl}, 10 \mathrm{mM}$ imidazole, $\mathrm{pH}$ 8.0) and lysed by sonication at $4{ }^{\circ} \mathrm{C}$. Soluble rEhRAD51 was purified near to homogeneity under denaturing and native conditions through $\mathrm{Ni}^{2+}$-NTA affinity chromatography according to the manufacturer recommendations (Qiagen). Purified rEhRAD51 identity and integrity were confirmed by $10 \%$ SDS-PAGE and Western blot assays using anti-6xHis tag antibodies (Roche) at 1:5000 dilution and the ECL Plus Western blotting detection system (Amersham).

Table 2: Primers used in RT-PCR assays

\begin{tabular}{|c|c|c|c|c|}
\hline Gene & Sense primer & Antisense primer & Amplified product (bp) & $\operatorname{Tm}\left({ }^{\circ} \mathrm{C}\right)$ \\
\hline Ehmre II & 5'-CGAGAAGAAGAGCAGCTCAA & 5'-СTTTCCTTTTTCTTCAGCCA & 391 & 49.5 \\
\hline Ehrad50 & 5'-CAGCCCAAGACATTCAAACA & 5'-CTGCATAATTGTTGTGCCAA & 277 & 49.5 \\
\hline Ehnbs I & 5'-САССТСССACACCACAGTAT & 5'-CTCCACCAATGAATGACCAT & 549 & 49.0 \\
\hline Ehrad5I & 5'-ATTGCTTTTACACCAAAG & 5'-TTCTTCTGAATTTAATCC & 400 & 49.5 \\
\hline Ehrad5 IC & 5'-CCACATGACATTGTGAGTCT & 5'-GAATTATCCGATGAAGTGCT & 155 & 45.0 \\
\hline Ehrad52 & 5'-ATGACTGAAATAGATACCTC & 5'-AATTTGATTGTTTTAAAGAAT & 730 & 37.5 \\
\hline Ehrad54 & 5'-GTCATGCCATTGACCAATTA & 5'-TCACACTCTTCCTCAGTTGG & 499 & 47.5 \\
\hline Ehrad54b & 5'-GGGCAAAAAATTCACCTAAA & 5'-GTCGTGATCCTCCAAGTGCT & 876 & 50.0 \\
\hline Ehrad52/22 & 5'-ATGTCTCATGAAATAAAACCAC & 5'-TCATTTCTTACGTCTAACTATTACT & 516 & 44.5 \\
\hline $25 S$ rRNA & 5'-TATCAAATCAAAGGACCCGCT & 5'-AAAAGA AAAACTAAGCGGTAA & 631 & 51.0 \\
\hline actin & 5'-AGCTGTTCTTTCATTATATGC & 5'-TTCTCTTTCAGCAGTAGTGGT & 220 & 48.0 \\
\hline
\end{tabular}




\section{Production of polyclonal antibodies raised against EhRAD5I}

Purified rEhRAD51 was submitted to preparative $10 \%$ SDS-PAGE, electroeluted from Coomassie stained-gels and subsequently used as antigen to immunize a New Zeland male rabbit. An initial dose of $200 \mu \mathrm{g}$ of rEhRAD51 in complete Freund's adjuvant (Sigma) was subcutaneously inoculated into the animal, and then three doses of $100 \mu \mathrm{g}$ in incomplete Freund's adjuvant were injected every 15 days. One week after the last immunization, the rabbit was bled and polyclonal antiserum was obtained. IgGs were purified through protein $G$ sepharose chromatography and tested for reactivity against rEhRAD51 protein by Western blot assays.

\section{Immunodetection of EhRAD5 I in subcellular extracts}

Western blot assays were performed using CE and NE proteins obtained before or $30 \mathrm{~min}$ after UV-C irradiation, and the membranes were incubated with anti-EhRAD51 polyclonal antibodies (1:1000 dilution) and goat antirabbit IgG horseradish peroxidase secondary antibody (Zymed)(1:10000 dilution). Immunodetected proteins were revealed with the ECL Plus Western blotting system (Amersham). The specificity of the anti-EhRAD51 antibodies was confirmed using anti-EhRAD51 antibodies pre-incubated with purified rEhRAD51 protein. As internal controls, we used polyclonal antibodies raised against the E. histolytica EhPAP [23] and actin proteins.

\section{Laser confocal microscopy assays}

Trophozoites were grown on sterile coverslips, fixed with $4 \%$ paraformaldehyde at $37^{\circ} \mathrm{C}$ for $1 \mathrm{~h}$, permeabilized with acetone and blocked with 1\% BSA/PBS. Next, cells were incubated with anti-EhRAD 51 polyclonal antibodies (1:200 dilution) at $37^{\circ} \mathrm{C}$ for $2 \mathrm{~h}$, followed by the anti-rabbit fluoresceinated monoclonal antibody (1:100 dilution) at $37^{\circ} \mathrm{C}$ for $1 \mathrm{~h}$. Then, trophozoites were washed three times with PBS $1 \times$ at room temperature and DNA was counterstained with propidium iodide $(5 \mu \mathrm{g} / \mathrm{ml})$ for 7 min. Light optical sections were obtained through a Nikon inverted microscope attached to a laser confocal scanning system (Leica) and analyzed by Confocal Assistant software Image J [45].

\section{DNA-binding assays}

For the electrophoretic mobility shift assay (EMSA), we used two DNA probes: a 50-nt ss oligonucleotide (adh50) from the Ehadh112 gene [46], which was $[\gamma-32 \mathrm{P}] \mathrm{dATP}$ (500 $\mu \mathrm{Ci} / \mathrm{mmol}$ ) 3 '-end labeled by $\mathrm{T} 4$ polynucleotide kinase at $37^{\circ} \mathrm{C}$ for $30 \mathrm{~min}$, and a 270 -bp dsDNA fragment (pgp270) of the 3'-UTR EhPgp5 gene [50] that was [ $\alpha$ 32P]dATP $(200 \mu \mathrm{Ci} / \mathrm{mmol})$ uniformly labeled by PCR. EMSA was carried out in a $25 \mu$ final volume reaction in binding buffer (50 mM Tris- $\mathrm{HCl} \mathrm{pH}$ 7.8, $1 \mathrm{mM}$ DTT, 10 $\left.\mathrm{mM} \mathrm{MgCl}{ }_{2}, 1 \mathrm{mM} \mathrm{ATP}\right)$ in the presence of increasing amounts of native rEhRAD51 (0, 2.5, 5 and $7.5 \mu \mathrm{g})$. Reactions were started by addition of $a d h 50$ or $p g p 270$ radiolabeled probes $(10000 \mathrm{cpm})$ at $37^{\circ} \mathrm{C}$ for $15 \mathrm{~min}$. Control assays were performed substituting purified rEhRAD 51 by the mock purified fraction obtained from untransformed bacteria. DNA-protein complexes were resolved on $6 \%$ non-denaturing TBE polyacrylamide gels, vacuum-dried and exposed to Phosphor Imager screen (BioRad).

\section{D-loop structure formation assay}

The EhRAD51 homologous DNA strand transfer activity was evaluated by the D-loop formation assay according to the described procedure [47]. A ssDNA fragment of 200 bases ( $p g p 200)$, which is complementary to the 3'-UTR Ehpgp5 gene cloned in the dsDNA plasmid [44], was $[\gamma$ $\left.{ }^{32} \mathrm{P}\right] \mathrm{dATP}(500 \mu \mathrm{Ci} / \mathrm{mmol}) 3^{3}$ '-end labeled by T4 polynucleotide kinase at $37^{\circ} \mathrm{C}$ for $30 \mathrm{~min}$. Increasing amounts of rEhRAD51 $(0,2.5,5$ and $7.5 \mu \mathrm{g})$ were pre-incubated in reaction buffer (50 mM Tris- $\mathrm{HCl} \mathrm{pH} 7.8,1 \mathrm{mM}$ DTT, 10 $\mathrm{mM} \mathrm{MgCl} 2$ and $1 \mathrm{mM} \mathrm{ATP)}$ with the $p g p 200$ probe $(10,000 \mathrm{cpm})$ at $37^{\circ} \mathrm{C}$ for $15 \mathrm{~min}$. Then, homologous dsDNA plasmid $(1 \mu \mathrm{M})$ was added and the mixture was incubated at $37^{\circ} \mathrm{C}$ for $30 \mathrm{~min}$. A non-related plasmid was used as heterologous dsDNA control. Reactions were stopped by addition of $0.1 \%$ SDS. To prevent that EhRAD51 binds and shifts the pgp200 probe, samples were deproteinized with proteinase $\mathrm{K}(1 \mathrm{mg} / \mathrm{ml})$ at $37^{\circ} \mathrm{C}$ for $10 \mathrm{~min}$. Then, they were fractionated by $1 \%$ agarose gel electrophoresis in TAE $1 \times$ buffer and transferred to a nylon membrane (Amersham) in SSC $20 \times$ solution overnight. Homologous DNA strand transfer activity of rEhRAD51 was evaluated through the visualization of radioactive DNA products in a Phosphor Imager (BioRad) and quantified by densitometry using the Quantity one software (BioRad).

\section{Authors' contributions}

MLC carried out most of the experiments and drafted the manuscript. EO participated in the study design, data interpretation and co-wrote the manuscript. Most of experiments presented here were performed in EO laboratory (CINVESTAV-IPN). LAM participated in the study design, data interpretation and bioinformatic analysis. CLC conceived the project, cloned the Ehrad51 gene, supervised the experiments and co-wrote the manuscript. All authors read and approved the final manuscript. 


\section{Additional material}

\section{Additional file 1}

Comparisons of EhRAD51 with orthologous proteins from other organisms. This table includes proteins homologous to EhRAD51 with respective homology/identity and e-values.

Click here for file

[http://www.biomedcentral.com/content/supplementary/1471-

2199-9-35-S1.doc]

\section{Additional file 2}

Predictions of EhRAD51 tertiary structure using the Swiss Model software and the yeast RAD51 protein crystal structure (PDB entry 1szp) as template. A. Predicted three-dimensional model of EhRAD51 protein showing the $N$-terminal domain (ND) constituted by a five- $\alpha$ helix bundle $(\alpha 1$ to $\alpha 5)$ and an ATPase domain (AD) conformed by a twisted central $\beta$-sheet, which includes $10 \beta$ strands sandwiched by $\alpha$-helices on both sides connected by a polymerization motif (PM). B. ATPase Walker A motif lies between $\beta 1$ and $\alpha 8$ and conserves the catalytic lysine (K160) and threonine (T160) residues, which are associated to ATP $\gamma$-phosphate contact and $\mathrm{Mg}^{2+}$ ion stabilization, respectively, in homologous proteins. Walker $B$ motif lies on $\beta 4$ and precedes $\alpha 12$ and the disordered DNA-binding loop 1. ATP cap is in close proximity to an ATP molecule. EhRAD51 DNA-binding loop 2 is formed by two inter-connected $\beta$ strands ( $\beta 6$ and $\beta 7)$. C. Three-dimensional representation of Polymerization motif (PM). Critical conserved residues conforming PM in helix 6 are shown. Key motifs were colored as follow: violet, PM; red, ATPase Walker A; green, Walker B; blue, ATP cap; yellow, Loop 1 and purple, Loop 2. Models were displayed and refined using the Pymol PBD viewer.

Click here for file

[http://www.biomedcentral.com/content/supplementary/14712199-9-35-S2.tiff]

\section{Acknowledgements}

Monoclonal anti-actin antibodies were gently donated by Dr. Manuel Hernandez (CINVESTAV-IPN). We are grateful to Victor Rosales (CINVESTAV-IPN) for helping us with the acquisition of FACS data and to M. Sc. Eduardo Carrillo (UACM) for laser confocal microscopy assistance. Our thanks are also to Alfredo Padilla and Sollange Archer (UACM) for their help in the artwork, as well as Dr. Rosana Arroyo for critical reading of manuscript. This work was supported by Mexican grants from UACM, CONACYT, COFAA-IPN and SIP-IPN.

\section{References}

I. Jackson T, Reddy S, Fincham J, bd-Alla M, Welles S, Ravdin J: A comparison of cross-sectional and longitudinal seroepidemiological assessments of entamoeba-infected populations in South Africa. Arch Med Res 2000, $31:$ S36-S37.

2. Orozco E, de la Cruz HF, Rodriguez MA: Isolation and characterization of Entamoeba histolytica mutants resistant to emetine. Mol Biochem Parasitol 1985, 15:49-59.

3. Zaki M, Meelu P, Sun W, Clark CG: Simultaneous differentiation and typing of Entamoeba histolytica and Entamoeba dispar. J Clin Microbiol 2002, 40: I 27I- 1276.

4. Báez-Camargo M, Gharaibeh R, Riverón AM, de la Cruz Hernández F, Luna JP, Gariglio P, Chávez P, Orozco E: Gene amplification in Entamoeba histolytica. Invasion Metastasis 1996, 16:269-279.

5. Lisby $M$, Rothstein R: DNA damage checkpoint and repair centers. Curr Opin Cell Biol 2004, 16:328-334.

6. Wei C, Skopp R, Takata M, Takeda S, Price CM: Effects of doublestrand break repair proteins on vertebrate telomere structure. Nucleic Acids Res 2002, 30:2862-2870.
7. Masson JY, West SC: The Rad5I and Dmcl recombinases: a non-identical twin relationship. Trends Biochem Sci 200I, 26:131-136.

8. van Attikum $\mathrm{H}$, Gasser SM: The histone code at DNA breaks: a guide to repair? Nat Rev Mol Cell Biol 2005, 6:757-765.

9. Longhese MP, Mantiero D, Clerici M: The cellular response to chromosome breakage. Mol Microbiol 2006, 60:1099-I I08.

10. Peck RF, DasSarma S, Krebs MP: Homologous gene knockout in the archaeon Halobacterium salinarum with ura3 as a counterselectable marker. Mol Microbiol 2000, 35:667-676.

II. Symington LS: Role of RAD52 epistasis group genes in homologous recombination and double-strand break repair. Microbiol Mol Biol Rev 2002, 66:630-700.

12. Thacker J: The RAD5 I gene family, genetic instability and cancer. Cancer Lett 2005, 21 9:125-135.

13. Paques F, Haber JE: Multiple pathways of recombination induced by double-strand breaks in Saccharomyces cerevisiae. Microbiol Mol Biol Rev 1999, 63:349-404.

14. Tashiro S, Walter J, Shinohara A, Kamada N, Cremer T: Rad5 I accumulation at sites of DNA damage and in postreplicative chromatin. J Cell Biol 2000, I 50:283-29I.

15. Bhattacharyya MK, Norris DE, Kumar N: Molecular players of homologous recombination in protozoan parasites: implications for generating antigenic variation. Infect Genet Evol 2004, 4:91-98.

16. Conway C, Proudfoot C, Burton P, Barry JD, McCulloch R: Two pathways of homologous recombination in Trypanosoma brucei. Mol Microbiol 2002, 45: 1687-1700.

17. Dzikowski R, Deitsch K: Antigenic variation by protozoan parasites: insights from Babesia bovis. Mol Microbiol 2006, 59:364-366.

18. Freitas-Junior LH, Bottius E, Pirrit LA, Deitsch KW, Scheidig C, Guinet $F$, Nehrbass U, Wellems TE, Scherf A: Frequent ectopic recombination of virulence factor genes in telomeric chromosome clusters of P. falciparum. Nature 2000, 407: $1018-1022$.

19. Triglia T, Foote SJ, Kemp DJ, Cowman AF: Amplification of the multidrug resistance gene pfmdrl in Plasmodium falciparum has arisen as multiple independent events. Mol Cell Biol |991, I I:5244-5250.

20. Woods WG, Dyall-Smith ML: Construction and analysis of a recombination-deficient (radA) mutant of Haloferax volcanii. Mol Microbiol 1997, 23:79|-797.

2I. Chen HT, Bhandoola A, Difilippantonio MJ, Zhu J, Brown MJ, Tai X, Rogakou EP, Brotz TM, Bonner WM, Ried T, Nussenzweig A: Response to RAG-mediated VDJ cleavage by NBSI and gamma-H2AX. Science 2000, 290:1962-1965.

22. Sullivan WJ Jr, Naguleswaran A, Angel SO: Histones and histone modifications in protozoan parasites. Cell Microbiol 2006, 8:|850-|86|.

23. Garcia-Vivas J, Lopez-Camarillo C, Azuara-Liceaga E, Orozco E, Marchat LA: Entamoeba histolytica: cloning and expression of the poly(A) polymerase EhPAP. Exp Parasitol 2005, I I 0:226-232.

24. Bell CE: Structure and mechanism of Escherichia coli RecA ATPase. Mol Microbiol 2005, 58:358-366.

25. Wu Y, Qian X, He Y, Moya IA, Luo Y: Crystal structure of an ATPase-active form of Rad5 I homolog from Methanococcus voltae. Insights into potassium dependence. J Biol Chem 2005, 280:722-728.

26. Shin DS, Pellegrini L, Daniels DS, Yelent B, Craig L, Bates D, Yu DS, Shivji MK, Hitomi C, Arvai AS, Volkmann N, Tsuruta $H$, Blundell TL, Venkitaraman AR, Tainer JA: Full-length archaeal Rad5 I structure and mutants: mechanisms for RAD5I assembly and control by BRCA2. EMBO J 2003, 22:4566-4576.

27. Conway $A B$, Lynch TW, Zhang Y, Fortin GS, Fung CW, Symington LS, Rice PA: Crystal structure of a Rad5 I filament. Nat Struct Mol Biol 2004, I I:791-796.

28. Birrell GW, Brown JA, Wu HI, Giaever G, Chu AM, Davis RW, Brown JM: Transcriptional response of Saccharomyces cerevisiae to DNA-damaging agents does not identify the genes that protect against these agents. Proc Nat/Acad Sci USA 2002, 99:8778-8783.

29. Garinis GA, Mitchell JR, Moorhouse MJ, Hanada K, de Waard H, Vandeputte D, Jans J, Brand K, Smid M, van der Spek PJ, Hoeijmakers $\mathrm{JH}$, Kanaar R, van der Horst GT: Transcriptome analysis reveals cyclobutane pyrimidine dimers as a major source of UVinduced DNA breaks. EMBO J 2005, 24:2952-2962. 
30. Campbell C, Romero DP: Identification and characterization of the RAD5 I gene from the ciliate Tetrahymena thermophila. Nucleic Acids Res 1998, 26:3165-3172.

31. McCready S, Muller JA, Boubriak I, Berquist BR, Ng WL, Dassarma S: UV irradiation induces homologous recombination genes in the model archaeon, Halobacterium sp. NRC-I. Saline Systems 2005, I:3.

32. Sørensen CS, Hansen LT, Dziegielewski J, Syljuåsen RG, Lundin C Bartek J, Helleday T: The cell-cycle checkpoint kinase Chk I is required for mammalian homologous recombination repair. Nat Cell Biol 2005, 7:195-201.

33. Haaf T, Golub El, Reddy G, Radding CM, Ward DC: Nuclear foci of mammalian Rad5 I recombination protein in somatic cells after DNA damage and its localization in synaptonemal complexes. Proc Natl Acad Sci USA 1995, 92:2298-2302.

34. Kant CR, Rao BJ, Sainis JK: DNA binding and pairing activity of OsDmcl, a recombinase from rice. Plant Mol Biol 2005, 57: I-I I.

35. Tombline G, Heinen CD, Shim KS, Fishel R: Biochemical characterization of the human RAD5 I protein. III. Modulation of DNA binding by adenosine nucleotides. I Biol Chem 2002, 277:|4434- |4442.

36. Orozco E, Suarez ME, Sanchez T: Differences in adhesion, phagocytosis and virulence of clones from Entamoeba histolytica, strain HMI:IMSS. Int J Parasitol 1985, I 5:655-660.

37. Tice RR, Agurell E, Anderson D, Burlinson B, Hartmann A, Kobayashi $\mathrm{H}$, Miyamae Y, Rojas E, Ryu JC, Sasaki YF: Single cell gel/comet assay: guidelines for in vitro and in vivo genetic toxicology testing. Environ Mol Mutagen 2000, 35:206-221.

38. The E. histolytica Pathema datatabase [http://pathema.tigr.org/ tigr-scripts/Entamoeba/PathemaHomePage.cgi]

39. Marchat LA, Pezet-Valdez M, Lopez-Camarillo C, Orozco E: Entamoeba histolytica: expression and DNA binding of CCAAT/ enhancer-binding proteins are regulated through the cell cycle. Exp Parasitol 2003, 103:82-87.

40. ClustalW software [http://www.ebi.ac.uk/clustalw/]

41. Prosite program [http://www.expasy.org/tools/scanprosite/]

42. Saitou N, Nei M: The neighbor-joining method: a new method for reconstructing phylogenetic trees. Mol Biol Evol 1987, 4:406-425.

43. MEGA version 3.I software [http://www.megasoftware.net]

44. Lopez-Camarillo C, Luna-Arias JP, Marchat LA, Orozco E: EhPgp5 mRNA stability is a regulatory event in the Entamoeba histolytica multidrug resistance phenotype. J Biol Chem 2003 278: I I 273-I I 280 .

45. Confocal Assistant software Image ] [http://rsb.info.nih.gov/ij/]

46. Banuelos C, Garcia-Rivera G, Lopez-Reyes I, Orozco E: Functional characterization of EhADHI I2: an Entamoeba histolytica Brol domain-containing protein. Exp Parasitol 2005 I I 0:292-297.

47. Kinebuchi T, Kagawa W, Enomoto R, Tanaka K, Miyagawa K, Shibata T, Kurumizaka H, Yokoyama S: Structural basis for octameric ring formation and DNA interaction of the human homologous-pairing protein Dmcl. Mol Cell 2004, I4:363-374.
Publish with Biomed Central and every scientist can read your work free of charge

"BioMed Central will be the most significant development for disseminating the results of biomedical research in our lifetime. "

Sir Paul Nurse, Cancer Research UK

Your research papers will be:

- available free of charge to the entire biomedical community

- peer reviewed and published immediately upon acceptance

- cited in PubMed and archived on PubMed Central

- yours - you keep the copyright
BiolMedcentral 